\title{
ANALISIS KEPUASAN MASYARAKAT TERHADAP KUALITAS PELAYANAN DALAM PENDAFTARAN TANAH PERTAMA KALI PADA KANTOR PERTANAHAN KABUPATEN BOGOR
}

\author{
Wawan Hermawan ${ }^{1 *}$, Dedi Budiman², Parulian Hutagaol ${ }^{2}$ \\ 1Badan Pertanahan Nasional, Jakarta 12110, Indonesia \\ 2Program Studi Ilmu Ekonomi, Fakultas Ekonomi Manajemen, Institut Pertanian Bogor, \\ Bogor 16680, Indonesia
}

*)E-mail: wawan_0762@yahoo.com

\begin{abstract}
Abstrak
Penelitian ini bertujuan untuk menganalisis tingkat kepuasan masyarakat terhadap pelayanan pendaftaran tanah di Kantor Pertanahan Kabupaten Bogor. Penelitian ini diharapkan dapat menemukan indikator yang menjadi prioritas dalam perbaikan kualitas pelayanan. Tingkat kepuasan masyarakat diukur menggunakan 5 dimensi, yaitu reliability, responsiveness, assurance, empathy, dan tangible. Berdasarkan hasil penelitian, dimensi kualitas pelayanan secara keseluruhan dalam pendaftaran tanah pertama kali melalui proses pengakuan hak yang diberikan oleh Kantor Pertanahan Kabupaten Bogor belum memenuhi kepuasan masyarakat. Ketidakpuasan masyarakat terhadap indikator kualitas pelayan ditandai selisih perolehan antara skor rata-rata kinerja sebesar 3,58 dengan skor rata-rata harapan sebesar 3,76 sehingga diperoleh skor rata-rata kesenjangan negatif sebesar $-0,18$. Indikator yang diprioritaskan untuk meningkatkan kepuasan masyarakat terhadap kualitas pelayanan pendaftaran tanah adalah kejelasan persyaratan pelayanan, kepastian biaya pelayanan, dan ketepatan waktu penyelesaian sertifikat. Implikasi manajerial peningkatan kepuasan pelayanan yang direkomendasikan yaitu perlu adanya penyesuaian standar persyaratan pelayanan, mengevaluasi dan mengkaji kebijakan yang sudah ada dan tidak relevan lagi untuk kondisi saat ini, membuat standar pelayanan yang lebih sederhana, menambah informasi pelayanan secara tertulis meningkatkan pengetahuan dan kemampuan pegawai melalui pendidikan dan pelatihan.
\end{abstract}

Kata kunci: Importance Performance Analysis (IPA), kepuasan konsumen, kualitas pelayanan, pendaftaran tanah

\section{Analysis of Community Satisfaction to The Service Quality in the First Land Registration in the Land Office of Bogor District}

\begin{abstract}
This study aimed to analyze the level of community satisfaction to the services of land registration in Land Office of Bogor. This study is expected to find indicators as a priority in the improvement of service quality. Level of community satisfaction was measured using five dimensions, i.e. reliability, responsiveness, assurance, empathy and tangible. Based on the results of the study, the overall dimensions of service quality in the first land registration through a process of the recognition of the rights granted by Land Office of Bogor District did not meet community satisfaction. Community dissatisfaction to the quality indicator of officer was marked by the difference between the average performance score of 3,58 with an average expectation score of 3,76 in order to obtain an average score of negative gap of $-0,18$. Indicators which are prioritized to improve community satisfaction with quality service of land registration are the clarity of service conditions, certainty of service cost, and timeliness of certificate completion. Managerial implication of recommended increasing satisfaction of service were a need to adjust the standard conditions of service, evaluating and reviewing existing policies and policies which are no longer relevant to the current conditions, creating a standard of service that is simpler, add service information in writing, improve the knowledge and abilities of employees through education and training.
\end{abstract}

Keywords : customer satisfaction, Importance Performance Analysis (IPA), land registration, service quality

\section{PENDAHULUAN}

Peningkatan pelayanan pertanahan yang berkualitas dan berasaskan keadilan oleh Kantor Pertanahan masih menjadi salah satu tuntutan masyarakat saat ini. Masyarakat beranggapan bahwa pelayanan di bidang pertanahan masih terlalu sulit dan berbelit-belit dalam prosedur, lama waktu pemrosesan, serta biaya yang tinggi walaupun ketentuanketentuan yang mengaturnya sudah ada dan sudah diimplementasikan. Kuantitas atau jumlah bidang tanah yang terdaftar di Kabupaten Bogor sesuai dengan laporan 
rekapitulasi hak atas tanah pada Kantor Pertanahan Kabupaten Bogor baru berjumlah \pm 938.670 bidang atau sebesar $\pm 43,0$ persen dari perkiraan total tanah yang ada. Jumlah tersebut tergolong sangat rendah. Oleh karena itu, perlu adanya percepatan dalam upaya mendukung kepastian dan perlindungan hukum bagi masyarakat untuk mengurangi kemungkinan terjadinya sengketa dan konflik pertanahan.

Banyaknya pengaduan dan keluhan dari masyarakat sebagai pengguna layanan disampaikan baik secara lisan, kelembagaan, maupun melalui media cetak dan media elektronik. Pengaduan tersebut mengenai ketidakpuasan atau kekecewaan masyarakat atas kualitas pelayanan yang diberikan oleh Kantor Pertanahan Kabupaten Bogor dalam pendaftaran tanah pertama kali melalui pengakuan hak. Hal ini mengisyaratkan bahwa kualitas pelayanan pada kantor pertanahan Kabupaten Bogor perlu diadakan pembenahan secara menyeluruh. Keterlambatan dalam penyelesaian sertifikat sebagai akibat buruknya kualitas pelayanan akan berdampak pada menurunnya produk sertifikat yang diselesaikan dan berpengaruh terhadap capaian kinerja dari Kantor Pertanahan Kabupaten Bogor. Berdasarkan laporan hasil rekapitulasi realisasi permohonan dan penyelesaian sertifikat pendaftaran tanah pertama kali melalui proses pengakuan hak pada bulan Januari sampai dengan bulan Desember tahun 2012, target penyelesaian sertifikat oleh Kantor Pertanahan Kabupaten Bogor tidak dapat terealisasi sesuai permohonan (Tabel 1).

Data pada Tabel 1 menunjukkan bahwa realisasi penyelesaian berkas permohonan sertifikat tidak sesuai target yang diinginkan dan menyisakan tunggakan pekerjaan yang setiap bulannya cenderung mengalami peningkatan jumlah permohonan yang tidak terselesaikan. Oleh karena itu, penelitian mengenai tingkat kepuasan masyarakat terhadap kualitas pelayanan dalam pendaftaran tanah pertama kali perlu dilakukan.

Kualitas pelayanan dipengaruhi oleh beberapa faktor yang dianggap penting bagi masyarakat dalam menggunakan layanan jasa. Menurut penelitian Azizah (2008) bahwa ketidakpuasan masyarakat terhadap kejelasan informasi pelayanan kemungkinan disebabkan oleh kemampuan petugas dalam menjelaskan informasi kepada masyarakat belum sesuai dengan harapan masyarakat. Dariah (2008) yang menganalisis pengaruh kualitas pelayanan terhadap kepuasan masyarakat menunjukkan bahwa faktor-faktor kualitas pelayanan jasa yaitu keandalan, daya tanggap, kepastian, empati, dan bukti fisik baik secara parsial ataupun simultan mempunyai pengaruh yang signifikan terhadap kepuasan masyarakat. Ketepatan waktu merupakan salah satu faktor penting bagi pelanggan (Hadiati \& Ruci, 1999). Danandjojo (2005) melakukan penelitian dengan judul "Kajian Kualitas Pelayanan Angkatan Laut Penumpang Jarak Dekat di Pelabuhan Tenau Kupang". Hasil analisis menggunakan Importance Performance Analysis (IPA) menunjukan bahwa nilai CSI pada pelabuhan ini sebesar 60,0 persen yang berarti very poor. Hasil penelitian juga menunjukkan bahwa beberapa aspek yang perlu diperbaiki adalah tingkat kemudahan informasi mengenai lokasi ruang tunggu, loket, tempat ibadah, toilet, dan fasilitas umum lainnya di atas kapal, serta kesesuaian tarif dengan pelayaran.

Tabel 1 Rekapitulasi realisasi permohonan dan penyelesaian pendaftaran tanah pertama kali (pengakuan hak) pada Bulan Januari-Desember tahun 2012

\begin{tabular}{llcccccc}
\hline No. & Bulan & $\begin{array}{c}\text { Sisa } \\
\text { Bulan }\end{array}$ & $\begin{array}{c}\text { Pendaftaran } \\
\text { lalu }\end{array}$ & Bulan ini & Jumlah & \multicolumn{3}{c}{ Penyelesaian Bulan ini } & \begin{tabular}{c} 
Sisa s/d \\
\cline { 6 - 7 } Bulan ini
\end{tabular} \\
\hline 1 & Januari & 4.052 & 960 & 5.012 & 431 & 709.132 & 4.581 \\
2 & Februari & 4.581 & 790 & 5.371 & 502 & 942.622 & 4.869 \\
3 & Maret & 4.869 & 540 & 5.409 & 629 & 1.366 .190 & 4.780 \\
4 & April & 4.780 & 543 & 5.323 & 554 & 737.338 & 4.769 \\
5 & Mei & 4.769 & 810 & 5.579 & 367 & 528.663 & 5.212 \\
6 & Juni & 5.212 & 554 & 5.766 & 593 & 821.046 & 5.173 \\
7 & Juli & 5.173 & 719 & 5.892 & 526 & 669.835 & 5.366 \\
8 & Agustus & 5.366 & 455 & 5.821 & 358 & 445.154 & 5.463 \\
9 & September & 5.463 & 511 & 5.974 & 214 & 290.853 & 5.760 \\
\hline
\end{tabular}


Kualitas pelayanan yang diberikan pemberi jasa akan berdampak pada kepuasan masyarakat pengguna jasa (pelanggan). Penelitian yang dilakukan oleh Prianggono dan Manupputy (2011) memperlihatkan bahwa terdapat pengaruh kualitas pelayanan terhadap kepuasan dalam pelayanan wajib pajak. Faktorfaktor yang memengaruhi kualitas pelayanan adalah faktor eksternal berupa tuntutan masyarakat terhadap pelayanan publik yang transparan, akuntabel, mudah, murah, cepat, dan tidak berbelit-belit. Faktor internal yaitu reformasi birokrasi Polri dan perubahan sistem pelayanan seperti perubahan tata layanan dan penerapan sistem ISO 9001 tahun 2008.

Saidani (2012) telah melakukan penelitian yang bertujuan untuk menguji pengaruh kualitas produk dan kualitas pelayanan untuk kepuasan konsumen dan niat membeli kembali dengan menggunakan Structural Equation Modeling (SEM). Hasil pengujian menujukkan bahwa kualitas produk dan kualitas pelayanan memengaruhi kepuasan pelanggan dan niat pembelian kembali. Produk dan layanan yang berkualitas memengaruhi kepuasan pelanggan dan pada akhirnya akan memengaruhi niat untuk melakukan pembelian kembali.

Penelitian yang mengukur tingkat kepuasan dan kualitas pelayanan dengan lima dimensi (reliability, responsiveness, assurance, empathy, dan tangible) telah dilakukan oleh beberapa peneliti sebelumnya. Hartati, Kadunci, dan Brida (2012) menunjukkan bahwa responsiveness, reliability, assurance, dan tangibles merupakan faktor-faktor determinan yang berpengaruh terhadap kepuasan pelanggan. Dalam penelitian tersebut, indikator yang menjadi prioritas adalah emphaty.

Selanjutnya, penelitian Yuliarmi dan Riyasa (2007) dan penelitian Yulianti dan Kurniawan (2011) dalam hasil penelitiannya menunjukkan secara bersama-sama atau simultan seluruh variabel berpengaruh signifikan terhadap kepuasan pelanggan, dan secara parsial ketanggapan, keyakinan, empathy, dan tangible berpengaruh signifikan positif terhadap kepuasan pelanggan, sedangkan faktor keandalan tidak berpengaruh signifikan positif terhadap kepuasan pelanggan. Berbeda dengan hasil penelitian sebelumnya, penelitian yang dilakukan oleh Nurbuat, Katili, dan Arina (2013) dan Vyandri, Hakim, dan Panirengu (2011) memperlihatkan bahwa kepuasan konsumen hanya dipengaruhi oleh dimensi reliability dan emphaty dan dimensi kualitas pelayanan yang paling dominan memengaruhi kepuasan konsumen adalah dimensi emphaty.
Siahaan (2012) melakukan penelitian mengenai pengaruh kualitas pelayanan terhadap kepuasan dan loyalitas nasabah tabungan. Hasil penelitian menunjukkan bahwa kualitas pelayanan berpengaruh sangat signifikan terhadap kepuasan nasabah. Secara parsial yang berpengaruh dominan adalah ketanggapan. Kepuasan nasabah berpengaruh signifikan terhadap loyalitas nasabah yang menunjukkan bahwa kepuasan nasabah terhadap kualitas pelayanan dapat meningkatkan loyalitas nasabah.

Penelitian-penelitian tersebut masih memerlukan penelitian lebih lanjut, yaitu tentang pemodelan struktural dari kualitas pelayanan dan kepuasan masyarakat, serta tidak menghasilkan indikator yang paling diprioritaskan untuk ditingkatkan kualitasnya. Dengan demikian, analisis tingkat kepuasan menggunakan model Importance Performance Analysis (IPA) dan konsentrasi penelitian untuk menganalisis indikator yang paling diprioritaskan untuk diperbaiki berdasarkan diagram kartesius diperlukan.

Penelitian ini menyajikan analisis kepuasan masyarakat melalui tingkat kesenjangan diantara kualitas kinerja dan harapan dari masyarakat. Analisis ini akan memberikan hasil atau memperoleh gambaran mengenai penilaian masyarakat terhadap indikatorindikator kualitas pelayanan. Hasil penilaian masyarakat secara keseluruhan terhadap indikator-indikator kualitas pelayanan pensertifikatan dikelompokkan menjadi empat kuadran.

\section{METODE}

Desain penelitian ini adalah cross sectional yang dilakukan di Kantor Pertanahan Kabupaten Bogor, Provinsi Jawa Barat. Penelitian dilakukan sejak bulan April sampai dengan bulan Juli tahun 2014. Responden dalam penelitian ini adalah masyarakat yang menggunakan jasa pelayanan pendaftaran tanah di Kantor Pertanahan Kabupaten Bogor. Keseluruhan responden berjumlah 120 orang yang dipilih dengan menggunakan teknik probability sampling.

Data primer dalam penelitian ini adalah karakteristik responden dan kepuasan masyarakat terhadap kualitas pelayanan dalam pendaftaran tanah pertama kali di kantor pertanahan. Karakteristik responden terdiri atas jenis kelamin, usia, tingkat pendidikan, jenis pekerjaan, dan pengalaman. Kepuasan masyarakat terhadap kualitas pelayanan kantor 
pertanahan diukur menggunakan kuesioner yang disusun berdasarkan konsep servqual (service quality) yang dikembangkan oleh Zeithaml, Parasuraman, dan Berry (1990) dengan melibatkan 5 dimensi, yaitu dimensi tangible, reliability, responsiveness, assurance, dan empathy. Kuesioner yang disusun terdiri atas 20 indikator kualitas pelayanan dan 20 indikator harapan pelayanan yang mana masing-masing dimensi terdiri atas 4 indikator dengan pilihan jawaban menggunakan skala Likert, yaitu sangat baik (skor 5), baik (skor 4), cukup baik (skor 3 ), kurang baik (skor 2), dan tidak baik (skor 1 ).

Selanjutnya, data yang diperoleh dianalisis menggunakan analisis deskriptif dan Importance Performance Analysis (IPA). Analisis deskriptif dilakukan untuk menghitung nilai rata-rata dari setiap indikator kualitas pelayanan. IPA digunakan untuk mengukur perbedaan antara yang diharapkan dan yang dipikirkan pelanggan atau perbedaan antara aspek harapan dengan kinerja pelayanannya. IPA merupakan analisis kepentingan dan kinerja digunakan untuk membandingkan antara kinerja suatu kegiatan yang dirasakan oleh pengguna layanan dengan tingkat kepuasan yang diinginkan. Skor penilaian menggunakan skala Likert 1-5, dengan penjelasan sebagai berikut: a) Skala 5 dinilai sangat penting diberikan dengan skor $5 ;$ b) Skala 4 dinilai penting diberikan dengan skor 4; c) Skala 3 dinilai cukup penting diberikan dengan skor 3; d) Skala 2 dinilai kurang penting diberikan dengan skor 2; 4) Skala 1 dinilai tidak penting diberikan dengan skor 1 . Selanjutnya indikator-indikator tersebut dijabarkan dan dibagi menjadi empat kuadran dalam Diagram Kartesius.

\section{HASIL}

\section{Karakteristik Responden}

Karakteristik responden terdiri atas jenis kelamin, usia, tingkat pendidikan, jenis pekerjaan, dan pengalaman dalam pengurusan permohonan sertifikat. Responden dalam penelitian ini terdiri atas 80,0 persen laki-laki dan 20,0 persen perempuan. Perbedaan jenis kelamin ini diduga mempunyai pengaruh terhadap persepsi responden mengenai pelayanan pensertifikatan tanah. $\mathrm{Hal}$ ini diperkuat hasil penelitian yang dilakukan oleh Dimitriades, Theodore, dan Maroudas (2007) bahwa jenis kelamin dan usia mempunyai pengaruh yang signifikan terhadap persepsi dalam pelayanan publik, yang mana laki-laki cenderung dapat mengevaluasi secara berbeda dan memberi nilai lebih tinggi terhadap pelayanan publik. Sebaran usia dalam penelitian ini menunjukkan bahwa tingkat masing-masing usia responden diduga mempunyai hubungan dengan persepsinya terhadap kualitas pelayanan pensertifikatan dalam pendaftaran tanah pertama kali melalui pengakuan hak.

Sebagian besar responden berpendidikan SLTA. Dengan demikian jelaslah bahwa tingkat pendidikan seseorang diduga akan memengaruhi sikap dan penilaiannya terhadap suatu permasalahan yang dihadapi dalam hal ini penilaian terhadap kualitas pelayanan yang diberikan dalam pengurusan sertifikat. Kategori jenis pekerjaan yang dimiliki responden persentase terbesar berada pada kelompok dengan jenis pekerjaan pegawai swasta yaitu sebanyak 35,0 persen. Pengalaman responden dalam pengurusan permohonan sertifikat dibagi empat kelompok, yaitu responden memiliki pengalaman 1 kali, 2 kali, 3 kali, dan 4 kali. Persentase terbesar yaitu 80,0 persen responden memiliki pengalaman satu kali dalam mengurus sertifikat. Berdasarkan tingkat pengalaman, pengalaman seseorang dalam mengurus sertifikat akan memengaruhi penilaiannya terhadap kualitas pelayanan.

\section{Tingkat Kepuasan Masyarakat terhadap Kualitas Pelayanan dalam Pendaftaran Tanah Pertama Kali}

Hasil penelitian penilaian tingkat kepuasan masyarakat secara keseluruhan terhadap indikator kualitas pelayanan pendaftaran tanah pertama kali dikelompokkan menjadi empat kuadran, yaitu kuadran I, kuadran II, kuadran III, dan kuadran IV. Adapun garis pembagi dalam analisis tersebut adalah nilai rata-rata dari skor rata-rata kinerja (performance) yaitu sebesar 3,58 dan nilai rata-rata dari skor ratarata kepentingan (importance) sebesar 3,76 (Gambar 1).

Kuadran I (Prioritas Utama). Kuadran ini terdiri atas indikator-indikator kualitas pelayanan memiliki nilai kepentingan yang relatif tinggi, namun nilai kinerjanya relatif rendah. Indikator yang berada di dalam kuadran ini adalah kejelasan persyaratan pelayanan (X5). Dengan demikian, kinerja harus ditingkatkan dengan melakukan perbaikan secara berkesinambungan berdasarkan hasil IPA yang diperoleh. 


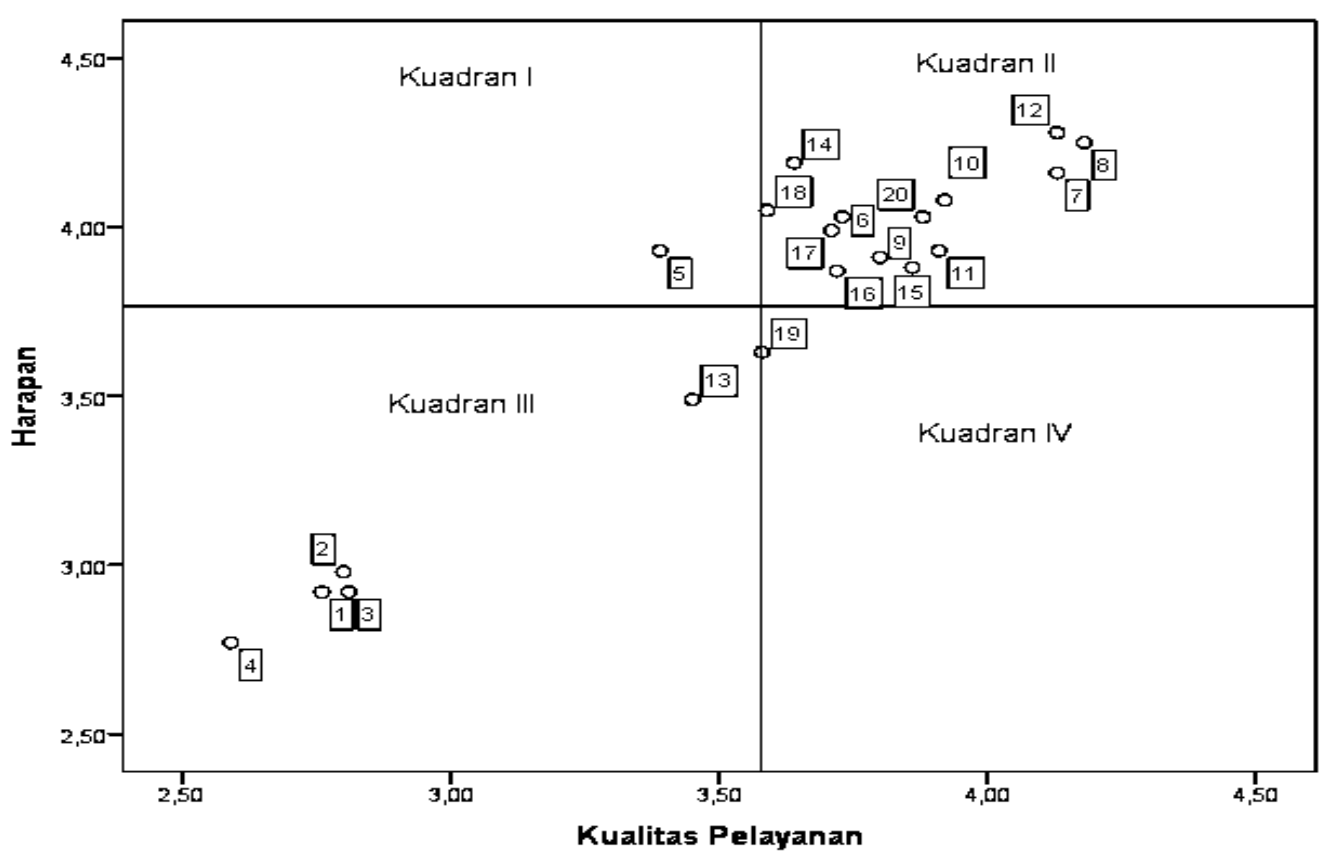

Gambar 1 Diagram kartesius antara kinerja dan harapan kualitas pelayanan

Kuadran II (Pertahankan Prestasi). Kuadran ini terdiri atas indikator-indikator kualitas pelayanan yang memiliki nilai kepentingan dan kinerja yang relatif tinggi. Indikator-indikator yang termasuk dalam kuadran ini dapat dipertahankan dan harus terus dikelola dengan baik karena memiliki keunggulan pelayanan dalam memberikan kepuasan masyarakat. Indikator yang termasuk dalam kuadran ini, yaitu kesederhanaan prosedur pelayanan (X6), kepastian biaya pelayanan (X7), ketepatan waktu penyelesaian sertifikat (X8), daya tanggap pegawai terhadap keluhan yang dihadapi masyarakat (X9), ketepatan dalam memberikan informasi pertanahan (X10), kecepatan pegawai dalam memberikan pelayanan (X11), ketepatan janji pegawai (X12), kejujuran pegawai dalam memberikan pelayanan (X14), tanggung jawab pegawai dalam pengelolaan berkas permohonan (X15), kesiapan pegawai melayani tepat waktu sesuai ketentuan jam kerja (X16), perhatian pegawai terhadap kebutuhan masyarakat (X17), keramahan sikap pegawai dalam memberikan pelayanan (X18), dan keikhlasan pegawai dalam memberikan pelayanan (X20).

Kuadran III (Prioritas Rendah). Kuadran ini memuat indikator-indikator kualitas pelayanan yang memiliki nilai kepentingan dan kinerja relatif rendah. Indikator-indikator kualitas pelayanan yang berada dalam kuadran ini tetap perlu dicermati karena kepentingan masyarakat dapat berubah dengan meningkatnya kebutuhan masyarakat terhadap jaminan kepastian hukum dan perlindungan hukum hak atas tanah. Indikator yang termasuk dalam kuadran ini, yaitu fasilitas fisik kantor (X1), ruang tunggu pelayanan (X2), keberadaan loket pelayanan $(X 3)$, penampilan pegawai dalam memberikan pelayanan (X4), kemampuan pegawai dalam memberikan pelayanan (X13).

Kuadran IV (Berlebihan). Kuadran ini terdiri atas indikator-indikator kualitas pelayanan yang memiliki nilai kepentingan relatif rendah, namun nilai kinerjanya relatif tinggi sehingga indicator pada kuadran ini dirasakan berlebihan oleh masyarakat. Indikator yang termasuk dalam kuadran ini adalah kesabaran pegawai dalam memberikan pelayanan (X19).

\section{Dimensi Kualitas Pelayanan}

Analisis mengenai tingkat kepuasan terhadap dimensi kualitas pelayanan dilakukan untuk menelaah seberapa besar suatu indikator dapat memenuhi kepuasan masyarakat terhadap kualitas pelayanan. Tingkat kepuasan ini dapat diperoleh dengan mengetahui besarnya nilai kesenjangan antara kinerja dan harapan. Kepuasan merupakan tingkat perasaan seseorang setelah membandingkan kinerja atau hasil yang dirasakannya dengan harapannya. Kepuasan juga didefinisikan sebagai salah satu ukuran keberhasilan dalam menyajikan pelayanan yang berkualitas sangat tergantung pada tingkat kepuasan pelanggan yang dilayani. Kepuasan pelanggan dapat dicapai apabila terdapat kesesuaian antara apa yang diharapkan oleh pelanggan dengan kenyataan yang didapatkan. Jadi, kepuasan 
sebagai tingkat perasaan seseorang setelah membandingkan kinerja (hasil) yang dirasakan dengan harapannya. Oleh karena itu, tingkat kepuasan merupakan fungsi dari perbedaan antara kinerja yang dirasakan dengan harapan. Indikator yang digunakan untuk mengukur kepuasan masyarakat terhadap kualitas pelayanan berdasarkan dimensi tangibles terdiri atas empat indikator yaitu fasilitas fisik kantor $\left(X_{1}\right)$, ruang tunggu pelayanan $\left(X_{2}\right)$, keberadaan loket pelayanan $\left(X_{3}\right)$, dan penampilan pegawai $\left(\mathrm{X}_{4}\right)$.

Indikator $X_{1}$ fasilitas fisik kantor, masyarakat merasa tidak puas terhadap fasilitas fisik kantor yang tersedia dalam mendukung pelayanan pensertifikatan. Hal ini ditunjukkan oleh nilai gap sebesar $-0,16$. Kondisi fasilitas fisik yang tersedia tidak terpelihara dengan baik. Selain itu, pemeliharaan fasilitas fisik lainnya tidak dilakukan secara rutin dan seringkali tidak berfungsi dengan baik. Hal tersebut diperkuat oleh pendapat Tjiptono (2002) bahwa jasa merupakan kinerja dan tidak dapat dirasakan sebagaimana halnya barang, maka pelanggan cenderung memperhatikan fakta-fakta tangibles yang berkaitan dengan jasa sebagai bukti kualitas.

Indikator $\mathrm{X}_{2}$ mempunyai nilai kesenjangan (GAP) negatif antara kinerja dan harapan yaitu sebesar $-0,18$. berarti masyarakat merasakan ketidakpuasan terhadap kenyamanan ruang tunggu pelayanan. Ketidakpuasan masyarakat tersebut disebabkan oleh kurangnya tempat duduk yang tersedia dan kualitas tempat duduk yang juga dinilai kurang nyaman, serta kondisi ruang tunggu yang tidak mempergunakan pendingin ruangan, terasa panas dan pengap, sehingga masyarakat berpersepsi kurang baik terhadap fasilitas pelayanan yang tersedia sebagai penunjang kelancaran pelaksanaan pekerjaan.

Indikator $\mathrm{X}_{3}$ keberadaannya saat ini dinilai tidak memuaskan. Masyarakat menilai bahwa keberadaan loket pelayanan yang tersedia belum memuaskan masyarakat, hal ini ditunjukkan oleh nilai kesenjangan yang negatif sebesar $-0,11$. Keberadaan loket pelayanan saat ini berada pada lantai yang berbeda. Masyarakat sangat mengharapkan agar loket pelayanan berada pada satu lantai yang sama untuk mempermudah proses pemberian pelayanan sesuai dengan fungsi masingmasing loket pelayanan, sehingga masyarakat dapat memperoleh kemudahan pelayanan tanpa harus berpindah-pindah tempat dari lantai satu ke lantai berikutnya.
Indikator $\mathrm{X}_{4}$ dinilai tidak memuaskan dengan GAP sebesar $-0,18$. Ketidakpuasan masyarakat ini ditunjukkan terutama dalam cara berpakaian petugas yang dinilai kurang rapi, penggunaan kelengkapan atribut yang tidak sesuai, serta tidak mempergunakan kartu pengenal sebagai identitas petugas. Hal ini diperkuat oleh pendapat Tjiptono (2002), bahwa untuk mencapai tingkat excellence setiap karyawan harus memiliki keterampilan tertentu, diantaranya berpenampilan baik dan rapi.

Indikator yang digunakan untuk mengukur tingkat kepuasan masyarakat terhadap kualitas pelayanan berdasarkan dimensi keandalan (reliability), terdiri atas kejelasan persyaratan pelayanan $\left(X_{5}\right)$, kesederhanan prosedur pelayanan $\left(X_{6}\right)$, kepastian biaya pelayanan $\left(X_{7}\right)$, dan ketepatan waktu pelayanan $\left(\mathrm{X}_{8}\right)$.

Indikator $X_{5}$, masyarakat merasa tidak puas terhadap kejelasan persyaratan dengan nilai GAP sebesar $-0,54$. ketidakpuasan masyarakat terhadap kejelasan persyaratan kemungkinan disebabkan kemampuan petugas dalam menjelaskan informasi kepada masyarakat belum sesuai dengan harapan masyarakat. Informasi mengenai persyaratan yang diberikan dirasakan sulit untuk dipahami dan dipenuhi kelengkapannya oleh masyarakat terutama dalam hal kelengkapan persyaratan berkas permohonan hak-hak lama.

Indikator $\mathrm{X}_{6}, \quad$ kesederhanaan prosedur pelayanan dirasakan tidak memuaskan masyarakat karena prosedur pelayanan yang sudah disusun secara sistematis dirasakan sulit untuk dimengerti oleh masyarakat dan dimungkinkan hanya dipahami oleh kalangan pegawai, karena tidak secara transparan informasi tersebut disampaikan. Masyarakat mengharapkan adanya kesederhanaan dalam prosedur pelayanan yang diberikan dan dapat dilaksanakan secara terbuka, tidak berbelitbelit, menggunakan bahasa yang sederhana agar mudah dimengerti dan dipahami.

Indikator $\mathrm{X}_{7}$ dinilai tidak memuaskan masyarakat. Ketidakpuasan ini terkait dengan biaya yang dikeluarkan dalam pengurusan permohonan sertifikat. Kepastian biaya pelayanan saat ini banyak mendapat perhatian masyarakat karena dinilai belum transparan, masih ditemukan adanya biaya yang harus dikeluarkan oleh masyarakat di luar biaya resmi atau sesuai ketentuan, sehingga masyarakat sulit mengalokasikan berapa biaya yang harus dikeluarkan dalam pengurusan permohonan sertifikat hak atas tanah. 
Indikator ketepatan waktu penyelesaian $X_{8}$ dinilai tidak memuaskan. Ketidakpuasan masyarakat terhadap ketepatan waktu penyelesaian sertifikat tanah seringkali dikeluhkan. Sebanyak 87,5 persen masyarakat membutuhkan waktu lebih dari 12 bulan untuk penyelesaian sertifikat. Hal ini dinilai oleh masyarakat terlalu lama. Ketepatan waktu penyelesaian sertifikat seringkali menimbulkan keraguan bagi masyarakat sebagai pemilik tanah terhadap kinerja kantor pertanahan dan keresahan terhadap status kepemilikan yang dimilikinya.

Indikator yang digunakan dalam mengukur tingkat kepuasan masyarakat terhadap kualitas pelayanan berdasarkan dimensi daya tanggap (responsiveness) terdiri atas empat indikator, yaitu daya tanggap pegawai terhadap keluhan masyarakat $\left(\mathrm{X}_{9}\right)$, ketepatan petugas dalam menyampaikan informasi $\left(\mathrm{X}_{10}\right)$, kecepatan pegawai dalam memberikan pelayanan $\left(\mathrm{X}_{11}\right)$, ketepatan janji pegawai $\left(\mathrm{X}_{12}\right)$.

Indikator $\mathrm{X}_{9}$ dinilai tidak memuaskan oleh masyarakat dengan nilai gap sebesar $-0,11$. Ketidakpuasan masyarakat ini tercermin dari banyaknya keluhan masyarakat atas pelayanan pertanahan yang kurang ditanggapi secara serius, sehingga timbul persepsi bahwa petugas kurang tanggap terhadap keluhan masyarakat. Keluhan masyarakat yang diajukan bisa menjadi umpan balik yang bersifat positif bagi usaha peningkatan kualitas pelayanan, dengan memberikan solusi terbaik maupun menjadi mediator dalam menyelesaikan permasalahan yang dihadapi oleh masyarakat.

Indikator $\mathrm{X}_{10}$ dinilai tidak memuaskan dengan nilai gap sebesar $-0,16$. Ketidakpuasan masyarakat terhadap ketepatan dalam memberikan informasi pertanahan tercermin dari pemberian informasi kepada masyarakat yang masih belum secara utuh tersampaikan dan tidak memenuhi harapan yang diinginkan. Hal ini diperkuat oleh pendapat Adnan (2007), yang mengatakan bahwa loket informasi mempunyai posisi sangat penting dan strategis karena merupakan pintu pertama yang mengawali proses kegiatan pelayanan pertanahan. Oleh karena kualitas hasil pelayanan pertanahan sangat tergantung pada hasil kerja petugas Loket I (informasi).

Indikator kecepatan pegawai dalam memberikan pelayanan $\left(\mathrm{X}_{11}\right)$ terhadap masyarakat dinilai tidak memuaskan. Ketidakpuasan masyarakat tercermin dari lambatnya pelayanan yang diberikan kepada masyarakat. Sebagai penyelenggaran pelayanan publik di bidang pertanahan, kantor pertanahan sesungguhnya berkewajiban memberikan pelayanan yang dapat diakses secarah mudah, murah, dan cepat.

Indikator ketepatan janji pegawai $\left(\mathrm{X}_{12}\right)$ dengan nilai gap sebesar $-0,15$ dinilai tidak memuaskan. Penilaian ini didasarkan pada tingkat kepuasan masyarakat terhadap janji pegawai dalam memberikan pelayanan sering menimbulkan kekecewaan yang selalu mengulur-ulur waktu dan memberikan harapan atau janji-janji kepada masyarakat tetapi pada kenyataannya tidak ditepati bahkan cenderung menghindar untuk ditemui, yang pada akhirnya dapat menyebabkan hilangnya rasa kepercayaan masyarakat terhadap kinerja pegawai kantor pertanahan.

Indikator yang digunakan untuk mengukur kepuasan masyarakat terhadap kualitas pelayanan berdasarkan dimensi kapastian (assurance) terdiri atas empat indikator, yaitu kemampuan pegawai dalam memberikan pelayanan $\left(X_{13}\right)$, kejujuran pegawai dalam memberikan pelayanan $\left(X_{14}\right)$, tanggung jawab pegawai dalam pengelolaan berkas permohonan $\left(\mathrm{X}_{15}\right)$, kesiapan pegawai melayani tepat waktu $\left(\mathrm{X}_{16}\right)$.

Indikator $\mathrm{X}_{13}$, kemampuan pegawai dalam memberikan pelayanan dinilai tidak puas oleh masyarakat. Ketidakpuasan ini ditunjukan oleh nilai gap sebesar -0,04. Ketidakpuasan masyarakat terhadap kemampuan pegawai dalam memberikan pelayanan akan berbeda satu sama yang lain, karena kemampuan pegawai pengaruhi oleh tingkat pengetahuan dan keahlian yang mereka miliki, sehingga sangat erat kaitannya dengan kualitas pelayanan yang diberikan oleh pegawai bersangkutan.

Indikator $\mathrm{X}_{14}$, responden memberikan nilai tidak memuaskan. Ketidakpuasan masyarakat tercermin dari sikap petugas yang dinilai belum berperilaku sesuai dengan tanggung jawab dan kewenangan yang diberikan, serta tidak transparan dalam memberikan pelayanan kepada masyarakat. Kejujuran akan memberikan dampak terhadap kepercayaan seseorang. Ratminto dan Winarsih (2006), mengatakan bahwa kejujuran sangat diperlukan karena akan mendorong petugas untuk melaksanakan tugas sesuai amanah yang diberikan.

Indikator $\mathrm{X}_{15}$, responden memberikan nilai tidak memuaskan, Ketidakpuasan masyarakat 
tercermin dari sikap pegawai yang dinilai belum bertanggung jawab, dan tidak transparan dalam pengelolaan berkas permohonan, masih dijumpai status berkas yang tidak jelas keberadaannya dan tidak diketemukan pada saat diperlukan, selain itu juga dokumen tercecer tidak pada tempatnya, sehingga proses pelaksanaan pekerjaan tidak berjalan sebagaimana mestinya.

Indikator $\mathrm{X}_{16}$, dinilai tidak memuaskan oleh masyarakat yang ditunjukkan pada nilai gap sebesar $-0,15$. Ketentuan jam kerja pegawai yang dimulai dari jam 8.00 wib, tetapi pegawai atau petugas loket pelayanan belum ada ditempat dalam arti belum siap melayani. Ketentuan jam kerja yang ditetapkan dirasakan masyarakat sangat kurang dan merugikan, dengan tingkat kedisiplin pegawai yang rendah terutama di loket pelayanan pendaftaran, sehingga mungkin tidak semua masyarakat dapat terlayani pada saat itu dan harus kembali pada keesokan harinya.

Indikator yang digunakan untuk mengukur kepuasan masyarakat terhadap kualitas pelayanan berdasarkan dimensi perhatian (empathy) terdiri atas empat, yaitu $\left(X_{17}\right)$ perhatian pegawai terhadap kebutuhan masyarakat, $\left(X_{18}\right)$ keramahan sikap pegawai dalam memberikan pelayanan, $\left(X_{19}\right)$ kesabaran petugas dalam melayani, $\left(\mathrm{X}_{20}\right)$ keikhlasan pegawai dalam memberikan pelayanan. Indikator $\left(X_{17}\right)$, dinilai tidak memuaskan dengan nilai gap sebesar -0,28, artinya kepuasan masyarakat untuk perhatian pegawai dalam memberikan pelayanan belum terpenuhi. Hal ini dikarenakan perhatian pegawai lebih mengutamakan untuk melayani staff PPAT dengan memberikan berbagai akses kemudahan dibandingkan melayani masyarakat pada umumnya. Hal inilah yang membuat masyarakat merasa tidak puas atas perhatian pegawai terhadap kebutuhan mereka.

Indikator $\mathrm{X}_{18}$, dinilai tidak memuaskan dengan nilai gap sebesar -0,46. Ketidakpuasan masyarakat tercermin dari penilaian intensitas pekerjaan petugas yang semakin meningkat sehingga mengurangi keramahan sikap dari pegawai dalam memberikan pelayanan. Kondisi ini menyebabkan kebutuhan masyarakat untuk dilayani tidak terpenuhi, sementara sebagian masyarakat belum mengerti dan memahami prosedur pelayanan di bidang pertanahan.

Indikator $\mathrm{X}_{19}$ tentang kesabaran petugas dalam memberikan pelayanan dinilai tidak memuaskan. Ketidakpuasan masyarakat tercermin dari perilaku petugas dalam memberikan pelayanan dilakukan tidak dengan sabar dan terkesan terburu-buru. Sikap dan keinginan masyarakat selalu berbeda-beda dalam oleh karena itu petugas dengan sikap profesionalnya harus melayani dengan sabar apa yang menjadi permintaannya, sehingga kesan yang diperoleh masyarakat terhadap pelayanan yang diberikan sesuai dengan harapannya. Indikator $X_{20}$, tentang keikhlasan pegawai dalam memberikan pelayanan, dinilai tidak memuaskan. Ketidakpuasan masyarakat tercermin dari sikap petugas yang tidak sepenuh hati bersedia membantu masyarakat, kurang bijak dalam menyikapi keluhan masyarakat dan mengharapkan sesuatu imbalan dengan kebaikan yang diberikannya dalam melayani masyarakat. Ketidakpuasan ditunjukkan oleh nilai gap yang negatif sebesar $-0,15$.

Berdasarkan analisis masing-masing dimensi kualitas pelayanan pendaftaran tanah diperoleh hasil bahwa secara keseluruhan kualitas pelayanan pendaftaran tanah yang diberikan oleh Kantor Pertanahan Kabupaten Bogor belum memberikan kepuasan pada masyarakat. Hal ini ditunjukkan oleh selisih perolehan antara skor rata-rata kinerja sebesar 3,58 dengan skor rata-rata harapan sebesar 3,76 sehingga diperoleh skor rata-rata kesenjangan negatif sebesar $-0,18$. Kesenjangan negatif ini memberi arti bahwa kualitas pelayanan pendaftaran tanah pertama kali yang telah diberikan oleh Kantor Pertahanan Kabupaten Bogor secara keseluruhan belum memberikan kepuasan bagi masyarakat. Kesenjangan negatif tersebut dapat terjadi karena ketidaksesuaian antara kinerja mengenai pelayanan yang dirasakan dengan pelayanan yang diharapkan oleh masyarakat. Sementara itu, hasil analisis pada setiap dimensi menunjukkan bahwa dimensi reliability dan empathy merupakan dimensi dengan kesenjangan yang paling besar antara kualitas layanan dan harapan. Sementara itu, kesenjangan terendah ditemukan pada dimensi responsiveness (Tabel 2 ).

Tabel 2 Kesenjangan antara harapan dan kualitas layanan

\begin{tabular}{llccc}
\hline & & \multicolumn{3}{c}{ Rata-rata } \\
\cline { 3 - 4 } No & Dimensi & $\begin{array}{c}\text { Kualitas } \\
\text { layanan } \\
\text { lX) }\end{array}$ & $\begin{array}{c}\text { Harapan } \\
(\mathrm{Y})\end{array}$ & GAP \\
\hline 1 & Tangible & 2,74 & 2,90 & $-0,16$ \\
2 & Reliability & 3,86 & 4,09 & $-0,24$ \\
3 & Responsiveness & 3,94 & 4,05 & $-0,11$ \\
4 & Assurace & 3,67 & 3,86 & $-0,19$ \\
5 & Emphaty & 3,69 & 3,93 & $-0,24$ \\
\hline & Total & 3,58 & 3,76 & $-0,18$ \\
\hline
\end{tabular}




\section{PEMBAHASAN}

Berdasarkan hasil penelitian prioritas peningkatan yang harus direkomendasikan untuk meningkatkan kepuasan masyarakat terhadap kualitas pelayanan adalah dimensi keandalan (reliability) pada indikator kualitas pelayanan kejelasan persyaratan pelayanan. Indikator kualitas pelayanan kejelasan persyaratan pelayanan persertifikatan memberikan kontribusi terbesar yaitu -0,54 yang berada pada kuadran I, yang mana menunjukkan wilayah dengan tingkat kepentingan yang relatif tinggi tetapi kenyataanya belum sesuai dengan harapan pelanggan. Menurut penelitian Azizah (2008) bahwa ketidakpuasan masyarakat terhadap kejelasan informasi pelayanan kemungkinan disebabkan oleh kemampuan petugas dalam menjelaskan informasi kepada masyarakat belum sesuai dengan harapan masyarakat. Persyaratan merupakan salah satu ketentuan yang harus dipenuhi oleh masyarakat untuk mengajukan permohonan pendaftaran tanah. Oleh karena itu, kantor pertanahan menyediakan loket informasi. Pada loket tersebut ditugaskan salah seorang staf untuk melayani dan menjelaskan semua informasi jenis pelayanan yang ingin diketahui oleh mayarakat yang berkaitan dengan proses pelayanan di bidang pertanahan.

Masyarakat yang membutuhkan informasi di Kantor Pertanahan Kabupaten Bogor setiap harinya cukup banyak dan tidak hanya pelayanan pendaftaran tanah pertama kali saja yang harus dilayani oleh petugas informasi. Semua jenis pelayanan yang ada pada Kantor Pertanahan juga menampung keluhan dari masyarakat berkenaan dengan persoalan pertanahan. Upaya untuk mengatasi tingginya jumlah permintaan informasi dan untuk memenuhi kepuasan masyarakat terhadap kejelasan persyaratan pelayanan pensertifikatan, yaitu dengan memfungsikan kembali loket pengaduan. Selain itu, perlu dilakukan upaya meningkatkan kemampuan pegawai yang bertugas pada loket informasi baik dalam teknis maupun nonteknis dan pegawai dituntut menguasai seluruh peraturan tentang pertanahan dan standar pelayanan pertanahan. Kebutuhan pegawai yang memiliki kemampuan tersebut mutlak diperlukan oleh kantor pertanahan sebagai penyedia layanan, karena akan berpengaruh terhadap kualitas pelayanan yang akan diberikan kepada masyarakat, khususnya cara penyampaian informasi terkait dengan kejelasan mengenai persyaratan yang harus dipenuhi untuk mengajukan permohonan pensertifikatan hak atas tanah.

Ketidakjelasan persyaratan pelayanan pensertifikatan yang disampaikan petugas di loket pelayanan informasi akan berdampak pada terhentinya proses permohonan dan penyelesaian penerbitan sertifikat. Berkas permohonan yang diajukan kurang lengkap harus mendapat perhatian lebih lanjut dengan memberikan informasi yang jelas dan transparan sekaligus memberikan informasi secara aktif kepada masyarakat agar masyarakat dapat segera melengkapi persyaratan yang diperlukan kantor pertanahan. Pemenuhan kelengkapan persyaratan oleh masyarakat memerlukan waktu yang lama meskipun sudah ada pemberitahuan secara resmi maupun melalui telepon langsung. Upaya perbaikan yang dapat dilakukan yaitu membangun pengertian dari masyarakat mengenai pentingnya persyaratan yang dibutuhkan dalam proses permohonan dan memberikan motivasi untuk memenuhi kekurangan persyaratan yang diminta. Motivasi tersebut dapat dilakukan dengan membantu memberikan solusi kepada masyarakat apabila mengalami kesulitan dalam melengkapi berkas. Pemberian solusi akan mendorong masyarakat untuk segera melengkapi berkas permohonan yang kurang, sehingga diharapkan permohonannya dapat diproses lebih lanjut di Kantor pertanahan.

Proses permohonan yang terhambat sebagai akibat dari ketidakjelasan persyaratan pelayanan disebabkan kurang lengkapnya informasi yang diperoleh masyarakat pada saat pengajuan permohonan. Keterlambatan juga akan berdampak pada ketepatan waktu pelayanan yang mana hal ini menunjukkan ketidakpuasan masyarakat terhadap pelayanan di kantor pertanahan (Sukirno, Mulyanto, \& Hakim, 2015). Hal ini diperjelas oleh pendapat Ratminto dan Winarsih (2006) yang mengemukakan bahwa untuk memenuhi kebutuhan informasi pelayanan kepada masyarakat, setiap unit pelayanan instansi pemerintah wajib mempublikasikan mengenai prosedur, biaya, waktu, serta pejabat/petugas yang berwenang. Sejalan dengan pernyataan Ratminto dan Winarsih (2006) bahwa masyarakat seringkali merasa kesulitan untuk mengakses layanan publik, padahal layanan publik adalah menjadi hak masyarakat. Fakta ini terjadi karena pemerintah kurang atau bahkan di beberapa tempat tidak pernah melakukan sosialisasi yang cukup tentang cara mengakses pelayanan publik. 
Berdasarkan uraian tersebut, untuk mengatasi ketidakjelasan persyaratan pelayanan dengan standar persyaratan pelayanan agar mengkaji ulang standar persyaratan yang sudah ditentukan dalam SP3. Hal ini dikarenakan standar persyaratan pensertifikatan dengan kenyataan persyaratan pensertifikatan terkait kejelasan persyaratan permohonan sertifikat hak atas tanah belum sesuai dengan harapan yang diinginkan. Kejelasan persyaratan pensertifikatan yang telah diatur dalam SP3 dengan kenyataan yang ada dapat diminimalkan dengan membuat standar persyaratan pelayanan yang lebih sederhana dan terperinci. Hal ini dilakukan agar mudah dipahami dan diakses oleh masyarakat sebagai pengguna layanan. Upaya untuk mengkaji persyaratan pokok lainnya yang melibatkan pihak ketiga khususnya pihak kelurahan diperlukan karena ketentuan mengenai persyaratan tersebut saat ini dirasakan sangat memberatkan bagi masyarakat.

Selain informasi pelayanan di bidang pertanahan secara transparan yang diberikan langsung kepada masyarakat, kantor pertanahan menambah informasi pelayanan secara tertulis di tempat yang mudah dan dapat terbaca oleh masyarakat. Informasi tersebut berupa booklet, banner, dan papan informasi yang memuat standar persyaratan pelayanan pendaftaran tanah yang lebih terperinci. Pemberian informasi melalui media cetak dan media elektronik juga sangat diperlukan, karena tidak menutup kemungkinan masyarakat merasa enggan untuk bertanya langsung ke kantor pertanahan karena alasan sibuk atau jauhnya jarak yang harus ditempuh dari tempat tinggal masyarakat saat ini dengan lokasi Kantor Pertanahan Kabupaten Bogor.

Pelaksanaan upaya perbaikan pelayanan di bidang pertanahan khususnya dalam hal kejelasan persyaratan pelayanan pensertifikatan diharapkan dapat dilaksanakan sesuai ketentuan. Hal ini juga diharapkan dapat meningkatkan kepuasan masyarakat terhadap kualitas pelayanan. Kepuasan masyarakat terhadap kejelasan persyaratan pelayanan pensertifikatan akan menumbuhkan tingkat kepercayaan masyarakat terhadap kinerja pelayanan publik khususnya pelayanan di bidang pertanahan.

\section{SIMPULAN DAN SARAN}

Kualitas pelayanan dalam pendaftaran tanah pertama kali melalui pengakuan hak yang diberikan oleh Kantor Pertanahan Kabupaten Bogor secara keseluruhan dinilai tidak memuaskan. Hal ini ditunjukkan oleh nilai ratarata kinerja yang lebih rendah dibandingkan dengan nilai rata-rata harapan. Adapun indikator yang perlu diprioritaskan untuk diperbaiki sebagai upaya untuk meningkatkan kepuasan masyarakat terhadap kualitas pelayanan, yaitu kejelasan persyaratan pelayanan. Upaya perbaikan yang direkomendasikan adalah memfungsikan loket pengaduan, meningkatkan kemampuan pegawai, membangun pengertian masyarakat tentang persyaratan, memberikan motivasi untuk melengkapi persyaratan, mengkaji ulang kelayakan persyaratan, membuat standar pelayanan yang lebih sederhana dan lebih terperinci agar mudah diakses masyarakat, dan menambah informasi persyaratan pelayanan secara tertulis ditempat yang mudah dan dapat terbaca oleh masyarakat.

Penelitian ini menyarankan perlu adanya kegiatan evaluasi fungsi loket pelayanan yang sudah tidak efektif dengan menempatkan pegawai yang mempunyai pengetahuan dan kemampuan teknis untuk meningkatkan kepuasan masyarakat terhadap kualitas pelayanan pendaftaran tanah pertama kali. Peningkatan kemampuan pegawai melalui pendidikan formal maupun nonformal, seperti pendidikan dan latihan (diklat) pegawai, baik diklat teknis maupun nonteknis sesuai bidang tugasnya masing-masing. Selain itu, perlu adanya kajian mengenai kelayakan standar pelayanan, standar persyaratan pelayanan pensertifikatan perlu disederhanakan dan dirinci sehingga mudah dipahami dan diakses oleh masyarakat. Kantor pertanahan juga perlu merumuskan strategi dalam rangka membangun pengertian kepada masyarakat tentang pertanahan melalui sosialisasi langsung ke masyarakat dan ke desa-desa.

\section{DAFTAR PUSTAKA}

Adnan, A. (2007). Studi penyusunan indikator kinerja pelayanan pertanahan: Dalam rangka kegiatan pendaftaran tanah untuk pertama kali. Makalah disampaikan dalam kegiatan desiminasi/seminar hasil-hasil penelitian Puslitbang BPN-RI di Bogor.

Azizah, N. (2008). Analisis kepuasan masyarakat terhadap pelayanan pendaftaran tanah (kasus: Kantor Pertanahan Kabupaten Bogor) (Tesis). Institut Pertanian Bogor, Bogor.

Danandjojo, I. (2005). Kajian kualitas pelayanan angkatan laut penumpang jarak dekat di Pelabuhan Tenau Kupang. Jurnal Penelitian Perhubungan, 7(17),13. 
Dariah. (2008). Pengaruh Kualitas Pelayanan Terhadap Kepuasan Masyarakat Dalam Mengurus Sertifikasi Tanah Pada Kantor Pertanahan Kota Banjarmasin. Jurnal Media Mahardika, 7(1).

Dimitriades, Z. S., Theodore, S., \& Maroudas. (2007). Demographic predictors of service satisfaction different for buyers/ user from different functional areas?. Measuring Business Excellent, 11(2), 32.

Hadiati, S., \& Ruci, S. (1999). Analisis kinerja kualitas pelayanan terhadap kepuasan pelanggan pada telkomsel Malang area. Jurnal Manajemen Kewirausahaan, 1(1), 56-64.

Hartati, T., Kadunci, \& Brida, L. (2011). Analisis pengaruh kualitas pelayanan terhadap kepuasan nasabah pegadaian di kodya depok. Jurnal Ekonomi Bisnis, 10(2), 152162.

Nurbuat, E. M., Katili, P. B., \& Arina, F. (2013). Analisis pengaruh kualitas pelayanan jasa terhadap kepuasan konsumen LP3G menggunakan structural equation modeling. Jurnal Tehnik Industri, 1(1), 5458.

Prianggono, J., \& Manupputy, D. E. S. (2011). Pengaruh kualitas pelayanan terhadap kepuasan wajib pajak dalam penerbitan surat tanda nomor kendaraan di Samsat Balikpapan. Jurnal Makna, 1(2), 59-74.

Ratminto., \& Winarsih, A. S. (2006). Manajemen Pelayanan Pengembangan Model Konseptual. Jakarta, ID: Pustaka Setia.

Saidani, B., \& Arifin, S. (2012). Pengaruh kualitas produk dan kualitas layanan terhadap kepuasan konsumen dan minat beli pada ranch market. Jurnal Riset Manajemen Sains Indonesia, 3(1), 1-22.

Siahaan, A. L. (2012). Pengaruh kualitas pelayanan terhadap kepuasan dan loyalitas nasabah tabungan britama pada PT. Bank Rakyat Indonesia (Persero) Tbk Cabang Sidikalang (Tesis). Universitas Sumatera Utara, Medan.

Sukirno, N., Mulyanto, B., \& Hakim, D. B. (2015). Analisis kesenjangan pada pelayanan pendaftaran tanah pertama kali di kantor pertanahan Kota Bekasi. Jur. IIm. Kel. \& Kons., 8(2), 106-114.

Tjiptono, F. (2002). Manajemen jasa. Yogyakarta, ID: Penerbit CV Andi Offset.

Vyandri, M. A., Hakim, A., \& Panirengu, S. (2011). Kepuasan masyarakat terhadap kualitas pelayanan pembuatan e-ktp. Jurnal Administrasi Publik, 2(2), 189-194.

Yulianti, F., \& Kurniawan, I. N. F. (2011). Pengaruh kualitas jasa terhadap kepuasan pelanggan pada PT. Kerta Gaya Pusaka Cabang Banjarmasin, Jurnal Spread, 1(1), 23-24.

Yuliarmi, N. N., \& Riyasa, P. (2007). Analisis faktor-faktor yang memengaruhi pelanggan terhadap pelayanan PDAM Kota Denpasar. Buletin Studi Ekonomi, 12(1), 927.

Zeithaml, V., Parasuraman, A., \& Berry, L. L. (1990). Delivering quality of service balancing customer perception and expectation. New York, US: Adivision of Macmillan, Inc. 